\title{
Three new species of Uvariodendron (Annonaceae) from coastal East Africa in Kenya and Tanzania
}

\author{
Léo-Paul M.J. Dagallier', Frank M. Mbago², \\ W.R. Quentin Luke, Thomas L.P. Couvreur ${ }^{1,4}$
}

I DIADE, Univ Montpellier, IRD, CIRAD, Montpellier, France 2 The Herbarium, Botany Department, Box 35060, University of Dar es Salaam, Dar es Salaam, Tanzania 3 East African Herbarium, National Museums of Kenya, P. O. Box 45166 00100, Nairobi, Kenya 4 Pontificia Universidad Católica del Ecuador, Facultad de Ciencias Exactas y Naturales Av. 12 de Octubre 1076 y Roca, Quito, Ecuador

Corresponding author: Léo-Paul M.J. Dagallier (leopauldagallier@gmail.com)

Academic editor: Y. Mutafchiev | Received 3 December 2020 | Accepted 21 January 2021 | Published 12 March 2021

Citation: Dagallier L-PMJ, Mbago FM, Luke WRQ, CouvreurTLP (2021) Three new species of Uvariodendron (Annonaceae) from coastal East Africa in Kenya and Tanzania. PhytoKeys 174: 107-126. https://doi.org/10.3897/phytokeys.174.61630

\begin{abstract}
East Africa is a hotspot of biodiversity with many endemic plant species. We describe three new species of the genus Uvariodendron (Annonaceae) from the coastal forests of Kenya and Tanzania. Uvariodendron mbagoi Dagallier \& Couvreur, sp. nov. is endemic to Tanzania and unique within the genus by its strong bergamot scent and its tomentose fruits having regular tufts of higher hair density. Uvariodendron dzomboense Dagallier, W.R.Q. Luke \& Couvreur, sp. nov. is endemic to Dzombo Hill in Kenya and is rendered distinct by its small leaves and very densely pubescent carpels. Uvariodendron schmidtii W.R.Q. Luke, Dagallier \& Couvreur, sp. nov. is endemic to Shimba Hills in Kenya and differs by its small flowers and fused sepals forming a ring. Following IUCN criteria we assessed U. mbagoi and $U$. dzomboense as endangered (EN) while U. schmidtii is assessed as Vulnerable (VU). We also propose a new combination: Polyceratocarpus oligocarpus (Verdc.) Dagallier, comb. nov. The description of these three new species underlines the richness in endemics in East Africa and that new discoveries might arise from further botanical exploration of this region.
\end{abstract}

\section{Keywords}

Annonaceae, bergamot, Dzombo Hill, endemic, IUCN conservation status, Shimba Hills

Copyright Léo-Paul M.J. Dagallier et al. This is an open access article distributed under the terms of the Creative Commons Attribution License (CC BY 4.0), which permits unrestricted use, distribution, and reproduction in any medium, provided the original author and source are credited. 


\section{Introduction}

East Africa is one of the richest regions in terms of biodiversity across the continent (Myers et al. 2000; Linder 2001). Recently, this region has been described as acting both as a "cradle" (i.e. promoting lineage divergence) and as a "museum" of diversity (i.e. maintaining old lineages), due to its topographical heterogeneity (Dagallier et al. 2020). East Africa harbors an incredible number of endemic species, particularly in the Eastern Arc Mountains and in coastal forests (Burgess et al. 1998, 2007; Küper et al. 2004). Despite the completion of the Flora of East Africa series (Beentje 2015), East Africa still needs further botanical exploration (Sosef et al. 2017). Indeed, from animals (Huber and Warui 2012) to plants (Poulsen and Lock 1997; Friis et al. 2015), new taxa continue to be described.

Annonaceae is a pantropical family of trees, shrubs and lianas. It is the most species rich family within the order Magnoliales, with ca. 2400 recognized species (Chatrou et al. 2012). In East Africa, several new species have been described for the region following the publication of the Flora of Tropical East Africa (Vollesen 1980; Verdcourt and Mwasumbi 1988; Johnson et al. 1999; Deroin and W.R.Q. Luke 2005; Couvreur et al. 2006; Couvreur and W.R.Q. Luke 2010; Marshall et al. 2016; Johnson et al. 2017; Gosline et al. 2019).

The genus Uvariodendron contains a total of 14 species restricted to tropical Africa (Fries 1930; Le Thomas 1967, 1969; Verdcourt 1969, 1986). It belongs to the Monodoreae tribe (Chatrou et al. 2012) and was inferred to be the sister genus to the Uvariopsis - Monocyclanthus clade based on molecular data (Couvreur et al. 2008; Guo et al. 2017). Like many Annonaceae species, Uvariodendron species are trees with simple hair indumentum and palgiotropic branches on an orthotropic axis. Their leaves are distichous, simple and entire, with the midrib sunken above, raised below, the secondary veins weakly brochidodromous to brochidodromous and the tertiary veins reticulate. They have hermaphroditic flowers with one whorl of three valvate to imbricate sepals and two whorls of three free and valvate petals. Uvariodendron species don't have a single synapomorphy that can differentiate them from other Annonaceae at first sight, but they can be recognized by the combination of the several characters presented hereafter. The inflorescence is axillary or on the trunk, composed of one to three sessile flowers or with a short pedicel (generally less than $5 \mathrm{~cm}$ ). The sepals are smaller than, and morphologically different to, the petals. The outer and inner petals are subequal in length, from 10 to $40 \mathrm{~mm}$ at anthesis; the outer petals are valvate all along the margin whereas inner petals are valvate only at the apex. The stamens are numerous (more than 200), with linear anthers and truncate connective. The carpels are free, linear, with a coiled stigma. The monocarps are sessile or subsessile and cylindrical.

Here we describe three new species of Uvariodendron, from coastal forests in Kenya and Tanzania. We also transfer the species known as Uvariodendron oligocarpum Verdc. within the genus Polyceratocarpus Engl. \& Diels as Polyceratocarpus oligocarpus (Verdc.) Dagallier. This brings the number of Uvariodendron species up to nine for East-Africa, and 17 for the genus as a whole. A key to East-African Uvariodendron species is also presented. 


\section{Material and methods}

We examined all the 35 herbarium specimens cited in the results. Among them, we measured 12 specimens for Uvariodendron mbagoi (three of which were also examined and measured as living individuals), three herbarium specimens for Uvariodendron dzomboense, and four herbarium specimens for Uvariodendron schmidtii. Herbarium specimens came from B, DSM, EA, K, MPU, MO, P, and WAG. The three new species are morphologically close to Uvariodendron kirkii Verdc., one of the other Uvariodendron species occurring in East Africa. In order to ease the discrimination between the species, we present a comparison table of the most discriminant characters between the four species (Table 1). The data for Uvariodendron kirkii is taken from Verdcourt (1971) and from more than 50 specimens examined in the above-mentioned herbaria.

For morphological descriptions, we followed the terminology developed by Hickey et al. (1999) and by the Systematics Association Committee for Descriptive Biological Terminology (1962) for leaf and plane shapes, by Payne (1978) for the indumentum, and by Harris and Harris (2001) for the other terms.

The identification key was built with the help of $\mathrm{Xper}^{3}$ comparison tools (http:// www.xper3.fr/, Vignes Lebbe et al. 2016).

To make a preliminary conservation status assessment for each species, we calculated the extent of occurrence (EOO) and the area of occupancy (AOO) using the ConR package (Dauby et al. 2017). When calculation of EOO and AOO was impossible due to imprecision of coordinates, as for Uvariodendron dzomboense and for Uvariodendron schmidtii, we calculated the area of the locality in which they occur (respectively the forested part of Dzombo Hill and the Longomwagandi forest) based on Google satellite images with the surface calculation tool in QGIS v. 2.18.17 (QGIS Development Team 2016). We then assigned a preliminary conservation status following IUCN Red List Categories and Criteria Version 3.1 (IUCN 2012).

The distribution map was plotted using ggmap (https://CRAN.R-project.org/ package=ggmap) package in $\mathrm{R}$ (R Core Team 2016). Data on protected areas was taken from Protected Planet (https://www.protectedplanet.net/, accessed June 2018).

\section{Results}

\section{Uvariodendron mbagoi Dagallier \& Couvreur, sp. nov.} urn:lsid:ipni.org:names:77215717-1

Fig. 1

Type. Tanzania - Tanga • L.-P.M.J. Dagallier 39 (holotype: MPU (MPU1375316), isotypes: DSM, K, MO, MPU (MPU1375317), P, WAG); Handeni District, Kwedijela forest, ca. 8 km from Kwamsisi village; 554'50.12"S, 38³6'12.35"E; alt. 156 m; 13 Nov. 2019.

Diagnosis. Differs from other Uvariodendron species by its stiff greyish-green leaves with slightly revolute margins, the strong bergamot scent (the citrusy smell of 
Table I. Comparison of the main characters used to discriminate the described species with Uvariondendron kirkii. In bold: character unique to the species.

\begin{tabular}{|c|c|c|c|c|}
\hline Species & U. kirkii & U. dzomboense & U. mbagoi & U. schmidtii \\
\hline Scent & none reported & none reported & strong, bergamot & none reported \\
\hline Lamina length (mm) & $86-210$ & $65-132$ & $76-157$ & $159-188$ \\
\hline Leaves margins & flat & slightly revolute & slightly revolute & flat \\
\hline Pedicel length (mm) & $5-28$ & $8-30$ & $0-0.6$ & $10-15$ \\
\hline Sepals & free, valvate to imbricate & fused at base & free, imbricate & fused, forming a ring \\
\hline Petals length (mm) & $12-39$ & $16-18$ & unknown on mature flower & $10-12$ \\
\hline Number of carpels & $7-20$ & $50-75$ & $12-16$ & $<10$ \\
\hline
\end{tabular}

Citrus bergamia Risso, between lemon and orange scent) of crushed leaves and bark, its globose flower buds easily falling off and its tomentose fruits having regular tufts of higher hair density. Differs from Uvariodendron kirkii by having smaller leaves when looking at the greater leaves (157 mm maximum vs. $210 \mathrm{~mm}$ maximum) (Table 1).

Description. Tree or shrub 3-6 m tall, 5-10 cm in diameter at breast height (d.b.h.), slash with strong bergamot smell (the citrusy smell of Citrus bergamia Risso); young branches sparsely pubescent to glabrous, old branches glabrous. Leaves distichous, simple, entire, margins slightly revolute, stiff, greyish-green. Petiole 3-6.5 mm long, $1.2-3 \mathrm{~mm}$ in diameter, young petiole sparsely pubescent to glabrous, old petiole glabrous. Leaf lamina 76-157 mm long, 31-59 mm wide, length:width ratio 2.2-3.5, narrowly elliptic to elliptic to narrowly obovate, between coriaceous and cartilaginous, apex acute to shortly acuminate, acumen 5-10 mm long, base acute to slightly decurrent (sometimes cuneate), above glabrous, below sparsely pubescent to glabrous when young, glabrous when old; mid rib sunken above, raised below, above glabrous when young and old, below sparsely pubescent to glabrous when young, glabrous when old; secondary veins 10-14 pairs, weakly brochidodromous, indistinct to slightly impressed above, slightly raised to raised below, inter-secondary veins absent; tertiary veins reticulate. Inflorescence borne on trunk or old branches, of 1-2 (3) flowers. Flower sessile or subsessile, pedicel $0-0.6 \mathrm{~mm}$ long, $2 \mathrm{~mm}$ in diameter. Flowers actinomorphic, hermaphroditic, buds globose 5-9 $\mathrm{mm}$ in diameter, velutinous, falling off very easily. Only flower buds and old fallen flowers seen. Bracts $2-5$, at base of the pedicel, upper bract 5-8 $\mathrm{mm}$ long, 10-15 $\mathrm{mm}$ wide, appressed, enclosing bud, pubescent outside, glabrous inside. Sepals 3, ca. 7-8 mm long, ca. 7-12 mm wide (measures taken from bud), imbricate, enclosing the petals in bud, velutinous outside, glabrous inside. Outer petals 3 , ca. $4 \mathrm{~mm}$ long, ca. $4 \mathrm{~mm}$ wide (measures taken from bud). Inner petals 3 , ca. $5 \mathrm{~mm}$ long, ca. $5 \mathrm{~mm}$ wide (measures taken from bud), shortly velutinous outside, glabrous inside. Stamens more than 400, mature length unknown, anthers linear, connective truncate. Carpels $12-16$, ca. $1.5 \mathrm{~mm}$ long, ca. $1 \mathrm{~mm}$ wide (measures taken from old flower), velutinous, stigma coiled. Fruiting pedicel $0-6 \mathrm{~mm}$ long, ca. $4 \mathrm{~mm}$ in diameter, pubescent. Monocarps 1-7, 20-50 mm long, 10-12 mm wide, length:width ratio $2-4.5$, cylindrical, generally curved, showing constrictions and longitudinally ridged, green-grey, tomentose with regular tufts of higher hair density, shortly stipitate, 

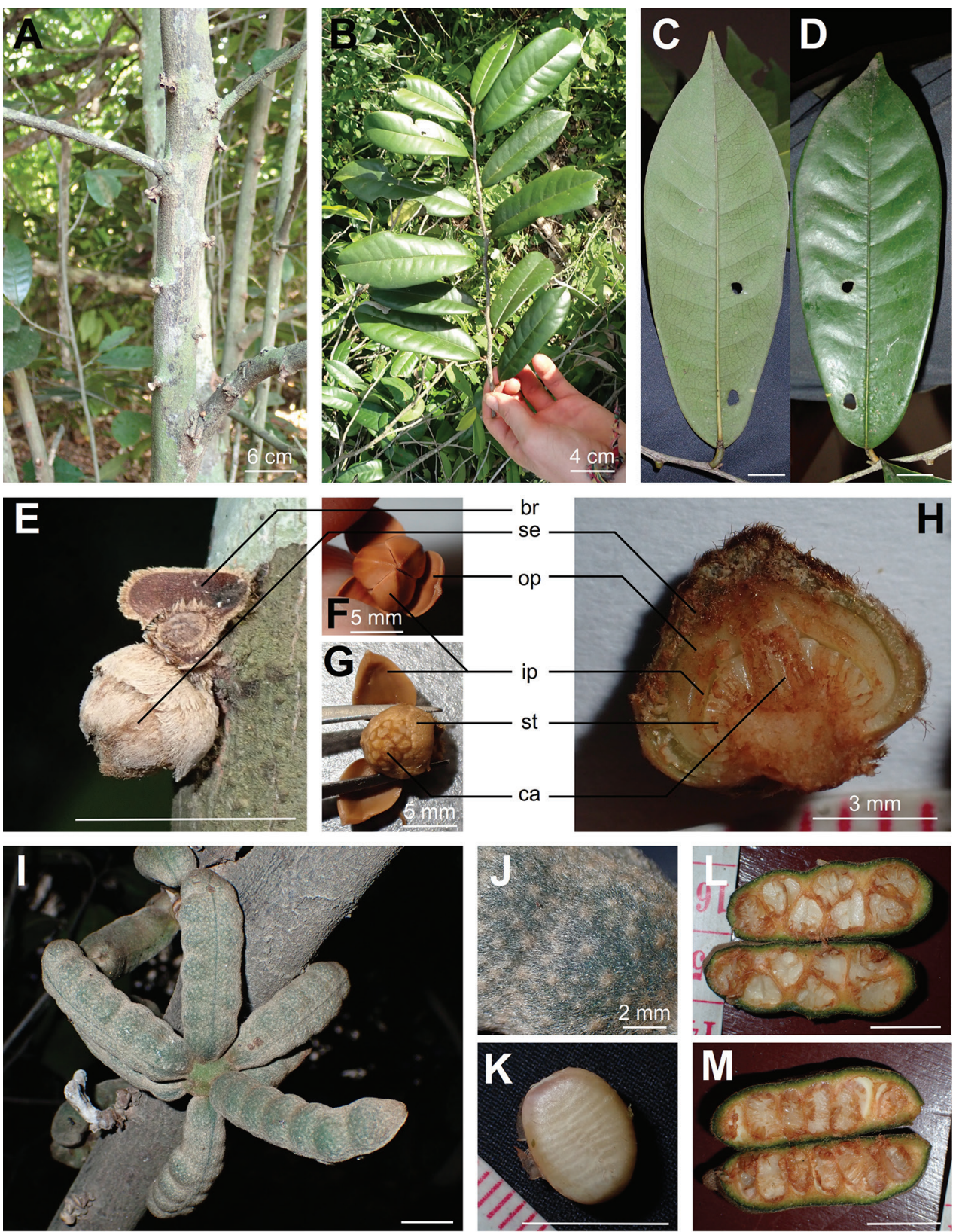

Figure I. Uvariodendron mbagoi A trunk with flower buds B young branch C, D entire leaf: C lower side $\mathbf{D}$ upper side $\mathbf{E}-\mathbf{H}$ pre-anthetic flower bud: $\mathbf{E}$ on trunk (bottom) and fallen flower bud (top) $\mathbf{F}$ seen from top with sepals removed $\mathbf{G}$ seen from top with outer petals removed $\mathbf{H}$ longitudinal section; $b r$ bract, ca carpel, ip inner petal, op outer petal, se sepal, st stamen I-M Fruit: I entire with 7 monocarps J indumentum $\mathbf{K}$ seed $\mathbf{L}$ tangential cut $\mathbf{M}$ longitudinal cut. Photos by L.-P. M.J. Dagallier from the specimens U. Bloesch s.n. (F, G), L.-P.M.J. Dagallier 39 (B, E, H, J, L), 40 (A, C, D) and 50 (I). Scale bars: 10 mm unless stated. 
stipe $0-1.5 \mathrm{~mm}$ long, $5 \mathrm{~mm}$ wide, tomentose. Seeds $4-17$ per monocarp, uniseriate to biseriate, $8-8.5 \mathrm{~mm}$ long, $5.5-6 \mathrm{~mm}$ wide, glabrous.

Habitat. Closed evergreen forest dominated by Scorodophloeus fischeri, on coral rag soil. Altitude: 90-340 meters.

Distribution. Endemic to Tanzania; only known from seven locations: Kimboza Forest, Msata Hill, Kwedijela forest, Kwedivikilo sacred forest, Mkwaja Ranch, Mkulumuzi river, and Hale (Fig. 2).

Conservation status. This species is known from 11 records in seven locations. The current occurrence of the species in Mkulumuzi river and Hale is really unlikely given that these are now (sub)urban areas and that these records date back, respectively, more than 30 years and over a century. Changes in traditional practices and exploitation of traditionally protected forests had been observed more than 20 years ago (Mwihomeke et al. 1998). This indicates that the current occurrence of the species in Kwedivikilo sacred forest is uncertain. Kwedijela forest is a locality under deforestation pressure with local crops slowly gaining ground (L-P.M.J. Dagallier and F. Mbago, field observations). However, the occurrences of the species in Kwedijela forest are 500 meters from the limit of Saadani National Park (SNP), so the species is likely to occur within the SNP where the protection is strict. The only record of this species occurring within a protected area is in Kimboza Forest Reserve, which has been threatened by encroachment, logging and invasion by the exotic Cedrela odorata L. (Hall and Rodgers 1986, Patrick 2008).

For the reasons explained above, we removed the occurrences in Mkulumuzi river and Hale from the calculations of extent of occurrence (EOO) and the area of occupancy (AOO). Considering the five remaining localities, the $\mathrm{EOO}$ is $3867 \mathrm{~km}^{2}$ and $\mathrm{AOO}$ is $20 \mathrm{~km}^{2}$. Following IUCN criterion B (IUCN 2012), Uvariodendron mbagoi is therefore assigned a preliminary status of Endangered EN B1ab(i,ii,iii,iv)+2ab(i,ii,iii,iv).

Vernacular names. Zigua (or Chizigua) language: Mchenene, Msenene (C.M. Kisena 3039), Mkenene (T.L.P. Couvreur 3, L-P.M.J. Dagallier 39, F. Mbago 3323).

Uses. The bark is used as a spice for meat meals and for tea.

Additional field notes. Foodplant of Graphium kirbyi (Papilionidae) (T.C.E. Congdon 532).

Etymology. Named after Mr. Frank Mbago, curator of the Dar es-Salaam University herbarium (DSM), to whom we owe the discovery of this species, and in honor of his botanic knowledge and fieldwork expertise in Tanzania, in particular of Annonaceae. He is also co-discoverer of the endemic Tanzanian genus Mwasumbia (Couvreur et al. 2009).

Paratypes. TANZANiA - Morogoro - L.-P.M.J. Dagallier 50 (DSM, K, MO, MPU (MPU1379109), P, WAG); Morogoro Rural District, Kimboza forest; 701'18.38"S, 3748'32.13"E; alt. 267 m; 15 Nov. 2019. - Pwani • U. Bloesch s.n. (WAG (WAG.1549674; WAG.1418750), Kwedijela Coastal Forest, T3; 555'00"S, 38³6'00"E; 18 Sep. 2004. • T.L.P. Couvreur 3 (DSM, WAG); Bagamoyo District, Mazizi hill, on road between Chilinze and Wami River; 6 22'14.4"S, 38²1'51"E; alt. 100 m; 09 Nov. 2006. • L.-P.M.J. Dagallier 1 (DSM, K, MO, MPU (MPU1379043, 


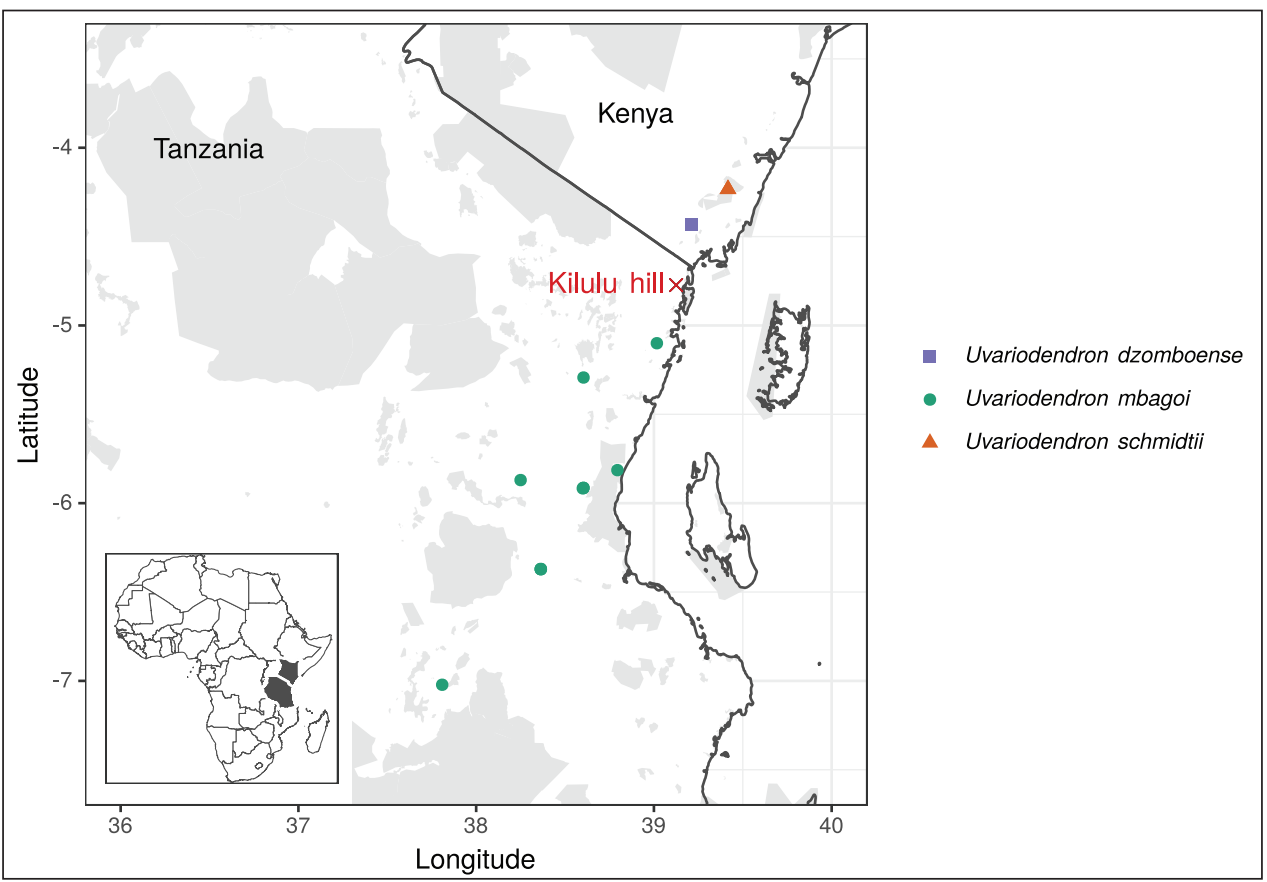

Figure 2. Map of the distribution of the three new Uvariodendron species. Protected areas are represented in grey shades (see Material and Methods for details). The red cross indicates Kilulu hill, where Uvariodendron dzomboense was expected to occur but was not found.

MPU1379066), P, WAG), Msata Hill, $30 \mathrm{~km}$ North of Chalinze; 6²2'17.78"S, 38²1'49.97"E; alt. 317 m; 06 Nov. 2019. - Tanga • T.C.E. Congdon 532 (K); Pangani District, Mkwaja Ranch; 548'50.76"S, 3847'40.92"E; alt. 90 m; 04 Dec. 1998. - L.-P.M.J. Dagallier 40 (DSM, K, MO, MPU (MPU1379099), P, WAG); Handeni District, Kwedijela forest, $-8 \mathrm{~km}$ Kwamsisi village; 554'50.77"S, 38³6'13.27"E; alt. 155 m; 13 Nov. 2019. • W.D. Hawthorne 1420A (K); Tanga District, Mkulumuzi river, karst river valley, Steinbruch reserve; 5006'00"S, 3901'00.12"E; 12 Aug. 1982. - C.M. Kisena 3039 (MO); Handeni District, Collected from Kwedivikilo sacred forest near Manga Village; 506'00"S, 30³7'00"E; 17 Nov. 1997. • F.M. Mbago 3323 (DSM, K); Handeni District, Kwedijela forest, -8 km Kwamsisi village; 5 54'50.77"S, 38³6'13.27"E; 07 Oct. 2004. • G.A. Peter 52283 (B, WAG, K), Inseln des Pangani bei Hale; 5¹7'34.8"S, 38³6'14.06"E; alt. 340 m; 31 Jan. 1915.

Discussion. Uvariodendron mbago is unique within Uvariodendron for the strong bergamot (Citrus bergamia Risso) scent of the crushed leaves and bark. This scent is between lemon and orange scent. Other African Annonaceae species present strong scents. For example, Uvariodendron anisatum Verdcourt (Verdcourt 1955) presents an aniseed scent, and Uvariodendron molundense (Diels) R.E. Fries var. citrata Le Thomas (Le Thomas 1969) and Uvariopsis citrata Couvreur \& Niangadouma (Couvreur and 
Niangadouma 2016), present a lemon scent. However, no bergamot scent has been reported so far in Annonaceae.

The globose flower buds of this species easily fall off. Only flower buds were observed for this species, thus it is hard to infer the size of mature flowers. In the description above, the measures on the sepals and the petals are based on the dissection of the biggest flower bud of U. Bloesch s.n., and the carpel measurements were based on an old flower of T.C.E. Congdon 532 which has lost sepals and petals.

The fruiting specimens observed were collected from September to December. Collecting this species earlier in the year might permit the observation of flowers at anthesis.

\section{Uvariodendron dzomboense Dagallier, W.R.Q. Luke \& Couvreur, sp. nov.} urn:Isid:ipni.org:names:77215718-1

Fig. 3

Type. Kenya - Coast - S.A. Robertson et al. Mrima Dzombo Expedition 207 (holotype: K, isotypes: EA, MO, WAG), Kaya Dzombo Hill; 4²5'48"S, 39¹2'36"E; alt. 300 m; 07 Feb. 1989.

Diagnosis. This species differs from other Uvariodendron species by its 50-75 carpels that are densely pubescent and its leaves smaller than $150 \mathrm{~mm}$ in length and narrowly elliptic to elliptic. It differs from $U$. kirkii by its smaller leaves $(132 \mathrm{~mm}$ maximum versus $210 \mathrm{~mm}$ maximum) and higher number of carpels (50-75 versus 7-20) (Table 1).

Description. Tree 4-7 m tall, d.b.h. unknown, young branches sparsely pubescent to glabrous, old branches glabrous. Leaf bud 'eragrostiform', composed of 5, distichous, longitudinally folded, velutinous scales. Leaves distichous, simple, entire, pinnately veined. Petiole $3-4 \mathrm{~mm}$ long, $1-1.5 \mathrm{~mm}$ in diameter, slightly pubescent to glabrous. Lamina 65-132 mm long, 20-45 mm wide, length:width ratio 2.9-3.6, narrowly elliptic to elliptic, coriaceous, apex attenuate, base acute to slightly decurrent, above glabrous, below glabrous when young and old; midrib sunken above, raised below, above glabrous when young and old, below slightly pubescent to glabrous when young, glabrous when old; secondary veins $12-13$ pairs, weak brochidodromous; tertiary veins reticulate. Inflorescence borne on trunk or old branches, 1-flowered. Flowering pedicel 8-30 mm long, 2-2.5 mm in diameter, densely pubescent. Flowers actinomorphic, hermaphroditic, buds spherical $4-4.5 \mathrm{~mm}$ in diameter, sparsely pubescent. Bracts 6 at base of the pedicel in flower bud, 1 on mature flower in the lower half of the pedicel, 5-6 mm long, 5-8 $\mathrm{mm}$ wide, pubescent to shortly pubescent outside, glabrous inside. Sepals 3, 5-7 mm long, 4.5-7 mm wide, fused at base, pubescent to shortly pubescent outside, glabrous inside. Outer petals 3, ca. $16 \mathrm{~mm}$ long, ca. $9 \mathrm{~mm}$ wide, shortly velutinous outside, glabrous inside, color unknown. Inner petals 3, ca. $18 \mathrm{~mm}$ long, $8 \mathrm{~mm}$ wide, shortly velutinous outside, glabrous inside, color unknown. Stamens more than 700, $2 \mathrm{~mm}$ long, $0.5 \mathrm{~mm}$ wide, anthers linear, connective truncate. Carpels 50-75, ca. $2 \mathrm{~mm}$ long, ca. $1-1.5 \mathrm{~mm}$ wide, densely pubescent. Stigma not seen. Fruiting pedicel ca. $14 \mathrm{~mm}$ long, ca. $4 \mathrm{~mm}$ in diameter, pubescent. Monocarps (unripe?) ca. 35, ca. 

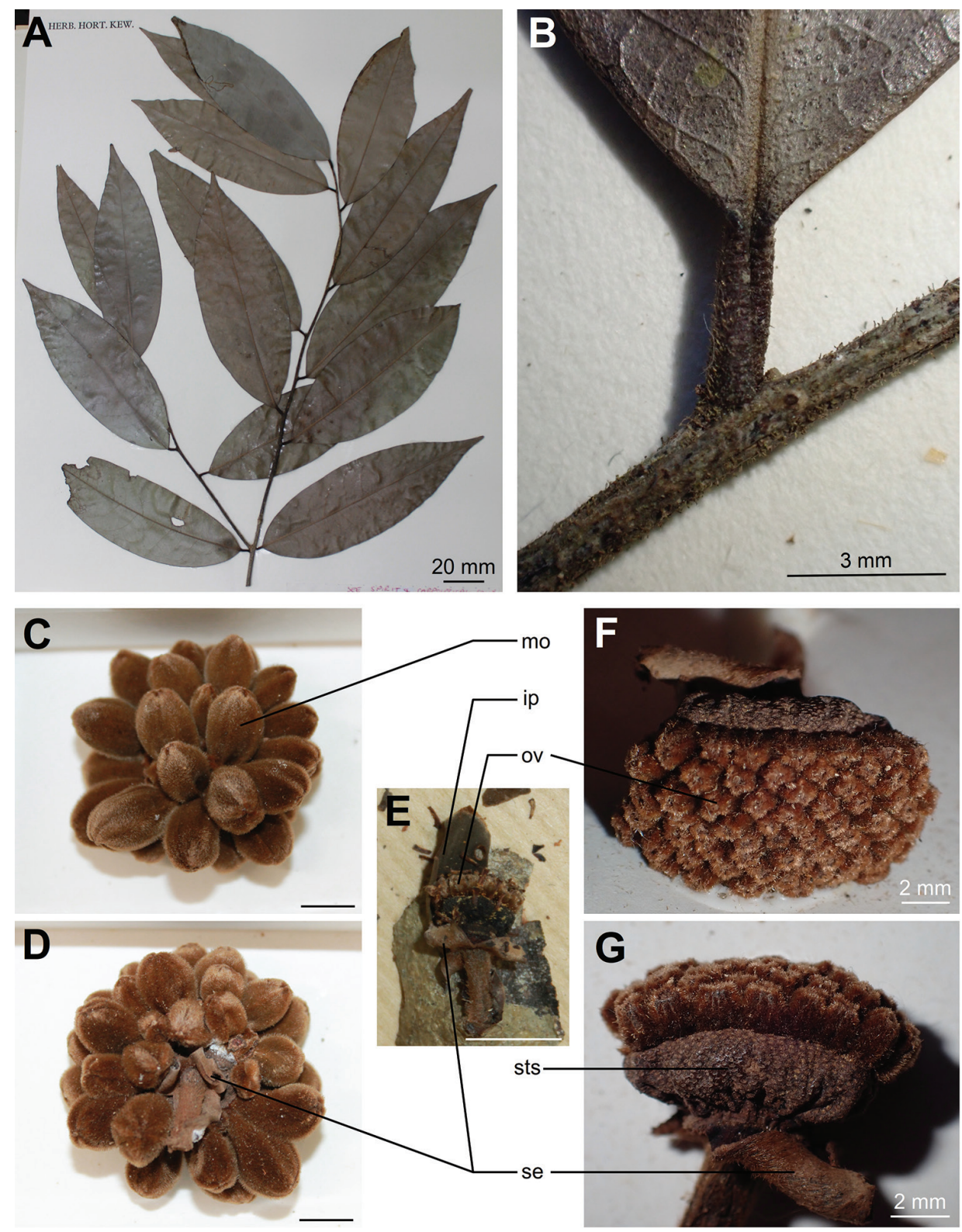

Figure 3. Uvariodendron dzomboense A young branch with leaves $\mathbf{B}$ petiole and young branch detail $\mathbf{C}, \mathbf{D}$ young fruit: $\mathbf{C}$ apical view $\mathbf{D}$ from the side $\mathbf{E}-\mathbf{G}$ old flower: $\mathbf{E}$ entire on trunk $\mathbf{F}$ from top with details of ovaries $\mathbf{G}$ close-up. ip inner petal, mo monocarp, ov ovary, se sepal, sts stamen scars. Photos by L.-P. M.J. Dagallier from the specimens W.R.Q. Luke 1654 (F, G), W.R.Q. Luke 7443 (B) and S.A. Robertson MDE 207 (A, C, D, F). Scale bars: $10 \mathrm{~mm}$ unless stated.

$15 \mathrm{~mm}$ long, ca. $10 \mathrm{~mm}$ wide, length:width ratio ca. 1.5 , ovoid, sessile, densely pubescent, golden brown. Seeds (unripe?) ca. 5 per monocarp, uniseriate, ca. $4.5 \mathrm{~mm}$ long, ca. $1 \mathrm{~mm}$ wide, glabrous. 
Distribution. Endemic to Kenya, only known from Dzombo Hill (Kaya Dzombo) (Fig. 2).

Habitat. Moist semi-deciduous forest on igneous intrusion.

Conservation status. This species is known from five collections from a single location. Literature found on the Dzombo Hill forest reports a surface of $2.95 \mathrm{~km}^{2}$ (Critical Ecosystem Partnership Fund 2005). We calculated a surface of $5.31 \mathrm{~km}^{2}$ for the forested part of the hill (see Material and Methods for details). EOO and AOO are thus estimated at less than $5.40 \mathrm{~km}^{2}$. The Kaya Dzombo forest is gazetted as a sacred forest under the National Museums protection as a National Monument. However, the forest suffers from local logging for timber, poles and firewood, and has been impacted by fire on several occasions (W.R.Q. Luke, personal observations). Following IUCN criterion B (IUCN 2012), Uvariodendron dzomboense is therefore assigned a preliminary status of Endangered EN B1ab(iii) $+2 \mathrm{ab}$ (iii).

Etymology. The specific epithet comes from the Dzombo Hill where the species is endemic.

Paratypes. KenYa - Coast - W.R.Q. Luke 1654 (EA (EA000008806), K); Kwale District, Dzombo Forest Reserve; 4²5'48"S, 39¹2'36"E; alt. 270 m; 06 Jan. 1989. • W.R.Q. Luke et al. 2884 (EA, K); Kwale District, Dzombo Forest Reserve; 4²5'48"S, 39¹2'36"E; alt. 270 m; 04 Oct. 1991. • W.R.Q. Luke et al. 3370 (EA); Kwale District, Dzombo Forest Reserve; 4²5'48"S, 39¹2'36"E; alt. 270 m; 12 Nov. 1992. • W.R.Q. Luke \& M. Pakia 7443 (K, EA (EA000008810)); Kwale District, Dzombo; $4^{\circ} 25^{\prime} 48^{\prime \prime S}, 39^{\circ} 12^{\prime} 36 " \mathrm{E}$; alt. 270 m; 28 Jun. 2001.

Discussion. This species is known as "Uvariodendron sp. nov. 1 of CFS" in the annotated checklist of the coastal forests of Kenya (Ngumbau et al. 2020).

The only fruit known from this species (Robertson S.A. et al. MDE 207) presents ca. 35 ovoid monocarps. These are densely pubescent and have small seeds compared to other Uvariodendron species ( $4.5 \mathrm{~mm}$ long vs. $8-20 \mathrm{~mm}$ long). However, it is unclear whether this observed fruit is ripe or not. Further collections could bring more information. This species also presents an 'eragrostiform' leaf-bud (see discussion of Uvariodendron schmidtii below).

During a field trip in Tanzania in November 2019, we explored the forest of Kilulu hill (TANZANIA- Tanga, $4^{\circ} 46^{\prime} 22^{\prime \prime} \mathrm{S}, 39^{\circ} 07^{\prime} 30^{\prime \prime} \mathrm{E}$, see Fig. 2). Kilulu hill is ca. 40 kilometers as the crow flies south from Dzombo hill were $U$. dzomboense occurs. We expected to find $U$. dzomboense there but our quest on every slope of the hill was unsuccessful. This indicates that the dispersal distance of $U$. dzomboense might be very short.

\section{Uvariodendron schmidtii W.R.Q. Luke, Dagallier \& Couvreur, sp. nov.} urn:Isid:ipni.org:names:77215719-1

Figure 4

Type. KenYa - Coast - W.R.Q. Luke 3087 (holotype: EA (EA000008814), isotypes: K, MO, US); Kwale District, Shimba hills, Longomagandi; 4 $14^{\prime} 00^{\prime S}$, $39^{\circ} 25^{\prime} 00^{\prime \prime E}$; alt. 380 m; 20 Apr. 1992. 
Diagnosis. This species differs from other Uvariodendron species by its flowers that are small (petals $<13 \mathrm{~mm}$ long), velutinous, on a 10-15 $\mathrm{mm}$ long pedicel, with fused sepals forming a ring around the fruit pedicel, and fewer than 10 carpels. It differs from $U$. kirkii by its smaller petals $(<13 \mathrm{~mm}$ versus more than $15 \mathrm{~mm})$ and its sepals fused in a ring (versus free and valvate to imbricate) (Table 1).

Description. Tree 10-12 m tall, d.b.h. unknown, young branches sparsely pubescent to glabrate, old branches glabrous. Leaf bud 'eragrostiform', composed of 5-7, ca. $10 \mathrm{~mm}$ long, $10 \mathrm{~mm}$ wide distichous, longitudinally folded, velutinous scales. Leaves distichous, simple, entire. Petiole $4.5-7 \mathrm{~mm}$ long, $1.5-2 \mathrm{~mm}$ in diameter, glabrate to sparsely puberulent. Lamina $159-188 \mathrm{~mm}$ long, 49-71 $\mathrm{mm}$ wide, length:width ratio 2.4-3.3, narrowly elliptic to elliptic, coriaceous, apex attenuate to acuminate, base acute to decurrent, above glabrous, below sparsely pubescent to glabrate when young, glabrous when old; midrib sunken above, raised below, above glabrous when young and old, below pubescent to glabrous when young, glabrous when old; secondary veins 10-14 pairs, weakly brochidodromous to brochidodromous; tertiary veins reticulate. Inflorescence borne on trunk and branches, 1-2 flowers. Flower pedicel 10-15 mm long, $2.5 \mathrm{~mm}$ in diameter, densely velutinous. Flowers actinomorphic, hermaphroditic, buds spherical, $6-7 \mathrm{~mm}$ in diameter, velutinous. Bracts $1-3,1$ at base of the pedicel, $1-2$ between the $20-70 \%$ of the length of the pedicel, ca. $5 \mathrm{~mm}$ long, ca. $10 \mathrm{~mm}$ wide, velutinous outside, glabrous inside. Sepals 3, 5.5-7 $\mathrm{mm}$ long, 7-9 $\mathrm{mm}$ wide, fused on ca. $50 \%$ of the length, forming a ring around fruit pedicel, densely velutinous to velutinous outside, glabrous inside. Outer petals 3, 11-12 mm long, 9-11 mm wide, densely velutinous to velutinous outside, glabrous inside, brown outside, cream with purple streak at base inside. Inner petals 3, ca. $10 \mathrm{~mm}$ long, 8-9 $\mathrm{mm}$ wide, connivent at apex on ca. $50 \%$ of the length, densely velutinous to velutinous outside, glabrous inside, brown-orange with margins cream and purple at base outside, cream with purple streak at base inside. Stamens more than 500, length and shape unknown. Carpels ca. 7, ca. $1.5 \mathrm{~mm}$ long, ca. $1 \mathrm{~mm}$ wide, velutinous. Stigma not seen. Fruiting pedicel ca. $16 \mathrm{~mm}$ long, ca. $2.5 \mathrm{~mm}$ in diameter, pubescent. Monocarps 3-5, ca. $32 \mathrm{~mm}$ long, ca. $20 \mathrm{~mm}$ wide, length:width ratio ca. 1.6, rounded to ellipsoid with a longitudinal ridge, sessile, sparsely pubescent, green turning orange. Seeds not seen.

Distribution. Endemic to Kenya; only known from the Longomwagandi forest (also found spelled "Longomagandi" or "Longo-Magandi" in the literature) in the Shimba Hills National Reserve, in Kenya (Fig. 2).

Habitat. Lowland forest on ridge with Antiaris, Milicia, Lovoa, Celtis, Quassia, Hymenaea, Julbernardia, Diospyros, Memecylon, and many Rubiaceae shrubs in understorey.

Conservation status. This species is known from seven collections from a single location. Literature for the Shimba Hills forest reserve reports a surface between $0.22 \mathrm{~km}^{2}$ (Schmidt 1992) and $1.50 \mathrm{~km}^{2}$ (Cheek 2003) for Longomwagandi forest. We calculated a surface of $1.30 \mathrm{~km}^{2}$ (see Material and methods for details). EOO and $\mathrm{AOO}$ are thus estimated at less than $1.50 \mathrm{~km}^{2}$. Following IUCN criterion $\mathrm{B}$, this would place the species in the "Critically Endangered CR" category. However, given that the occurrences are in the Shimba Hills National Reserve, no decline is observed or projected in EOO and AOO. The future of Uvariodendron schmidtii relies on the 

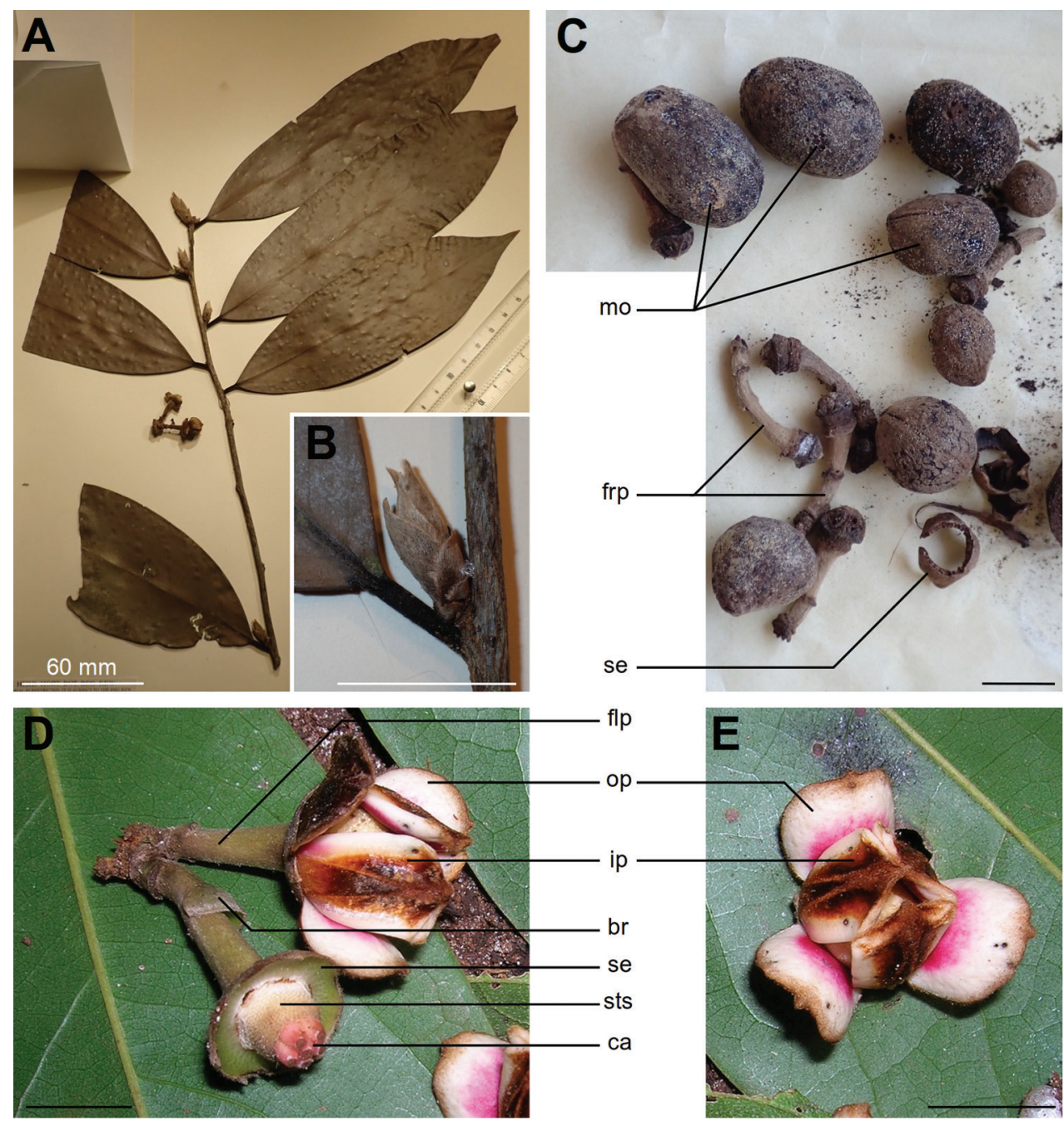

Figure 4. Uvariodendron schmidtii $\mathbf{A}$ young branch with leaves $\mathbf{B}$ eragrostiform axillary bud $\mathbf{C}$ detached monocarps and pedicels $\mathbf{D}$ two-flowered inflorescence $\mathbf{E}$ flower, apical view. $b r$ bract, $c a$ carpel, $f p$ flower pedicel, frp fruit pedicel, $i p$ inner petal, mo monocarp, op outer petal, se sepals ring, sts stamen scars. Photos by L.-P. M.J. Dagallier from the specimens W.R.Q. Luke 3087 (C) and W.R.Q Luke 4717 (A, B), and by W.R.Q. Luke from a living individual (D, E). Scale bars: $10 \mathrm{~mm}$ unless stated.

future of Shimba Hills National Reserve. Given that the species occurs in a single locality with a very restricted $\mathrm{AOO}$ (less than $20 \mathrm{~km}^{2}$ ), it is "prone to the effects of human activities or stochastic events within a very short time period in an uncertain future, and is thus capable of becoming Critically Endangered or even Extinct in a very short time period" (IUCN 2012). Following IUCN criterion D, it can be therefore assigned a preliminary status of Vulnerable VU. 
Copious seedlings are found below parent trees, but few survive to maturity. Many of these "wildlings" were moved to the Base Titanium indigenous tree nursery and have been out-planted there as part of their mine rehabilitation program.

Vernacular name. Mbebeneka in Kidigo language (R. Schmidt 788).

Etymology. This species is named after Robert Schmidt, a PhD student studying the ecology of the Shimba Hills National Reserve who first collected it in September 1988 and brought it to the attention of W.R.Q. Luke.

Paratypes. KenYa - Coast - W.R.Q. Luke \& S.A. Robertson 2737 (EA, K, MO, US); Kwale District, Shimba hills, Longomagandi; $4^{\circ} 14^{\prime} 00^{\prime \prime S}, 39^{\circ} 25^{\prime} 00^{\prime \prime E}$; alt. 390 m; 18 Mar. 1991. • W.R.Q. Luke 2919 (EA (EA000008817), K, MO, US); Kwale District, Shimba hills, Longomagandi; $4^{\circ} 14^{\prime} 00^{\prime \prime S}, 39^{\circ} 25^{\prime} 00 " \mathrm{E}$; alt. 390 m; 15 Oct. 1991. • W.R.Q. Luke 4717 (P (P02084012), Ukunda); Kwale District, Shimba hills, Longomwagandi; 4014'00"S, 39²5'00"E; alt. 380 m; 12 Sep. 1997. - W.R.Q. Luke 11676 (EA, K, MO, US); Kwale District, Shimba hills, Longomagandi; $4^{\circ} 14^{\prime} 00^{\prime S}, 39^{\circ} 25^{\prime} 00^{\prime \prime E}$; alt. 380 m; 30 Dec. 2006. • S.A. Robertson 7556 (EA, K, WAG (WAG0129164)); Kwale District, Shimba Hills, Longomagandi; 4ำ1'00"S, 39²5'00"E; alt. 450 m; 04 Jun. 2005. • R. Schmidt 788 (EA); Kwale District, Shimba Hills, Longomagandi; 07 Sep. 1988.

Discussion. This species shows 'eragrostiform' leaf-buds, a feature described in Uvariodendron gorgonis Verdcourt (Verdcourt 1969) and Uvariodendron dzomboense Dagallier, W.R.Q. Luke \& Couvreur (this publication). This structure is composed of several (5-7 in U. schmidtii and U. dzomboense, 6-12 in U. gorgonis) distichous and densely pubescent scales that might be a protection for the apical meristem against drought or herbivores. The adjective 'eragrostiform' refers to the genus Eragrostis (Poaceae) that has a peculiar form of flattened spikelet composed of compact and clustered florets. Even though this feature is striking, it seems hard to use it as a diagnostic character. Similar apical buds are also found in other Annonaceae species such as Monodora minor Engler \& Diels (Couvreur 2009) or in Uvariodendron usambarense Fries and Uvariodendron giganteum (Engler) Fries.

\section{Polyceratocarpus oligocarpus (Verdc.) Dagallier, comb. nov.} urn:Isid:ipni.org:names:77215720-1

Uvariodendron oligocarpum Verdcourt, Kew Bulletin 41(2): 289, 1986.

Type. Tanzania - Tanga • J. Lovett 259 (holotype: K (K000198888)); Lushoto District, Ambangulu, West Usambara; alt. 1300 m; 2 Mar. 1984.

We examined 11 specimens (including the type specimen) of Uvariodendron oligocarpum Verdc. and found they have percurrent tertiary venation and pitted seeds. These characteristics are typical of the genus Polyceratocarpus Engl. \& Diels (Couvreur et al. 2009, 2012). Moreover, the fertile specimens observed have the 
combination of the following characters: outer petals ca. $35 \mathrm{~mm}$ long, 3 to 6 carpels, and 2 to 4 cylindrical and straight to slightly curved monocarps. This combination precludes these specimens from being identified as one of the two other species known from East Africa to date: Polyceratocarpus scheffleri Engl. \& Diels that has "at least 20 [and] strongly curved" monocarps (Verdcourt 1971), and Polyceratocarpus askhambryan-iringae A.R. Marshall \& D.M. Johnson that has outer petals 10-16 mm long (Marshall et al. 2016). Based on the above characters, they also cannot be included in any other accepted species from Central or West Africa that all have petals shorter than $25 \mathrm{~mm}$ long: Polyceratocarpus angustifolius Paiva and P. germanii Boutique, P. gossweileri (Excell) Paiva, P. laurifolius Paiva, P. microtrichus (Engl. \& Diels) Ghesq. ex Pellegr., P. parviflorus Ghesq., and P. pellegrinii Le Thomas (Pellegrin 1949, Boutique 1951, Le Thomas 1965, Paiva 1966). Thus, this species initially described as Uvariodendron oligocarpum Verdc. is here combined as Polyceratocarpus oligocarpus (Verdc.) Dagallier.

Other specimen examined. TANZANIA - Tanga • A. Borhidi 86249 (K); Muheza District, East Usambaras Mts., Kwamkoro F.R. SE of Kwamkoro Tea Estate; alt. 1030 m; 28 Oct. 1986. • A. Borhidi 87241 (K); Muheza District, East Usambaras Mts., Kwamkoro F.R. bordering Kwamsambia F.R; alt. 990 m; 05 May. 1987. • L.-P.M.J. Dagallier 63 (DSM, K, MPU (MPU1379122), P, WAG); Korogwe District, East Usambaras, Ambangulu, top of the mountain above the tea plantations; 504'13.00"S, 38²4'31.00"E; alt. 1320 m; 20 Nov. 2019. • A.R. Marshall 1457 (K, MO); Lushoto District, Ambangulu - PSP19, Ambangulu Tea Estate Forest, West Usambara Mountains; 54'20.69"S, 38²4'24.21"E; alt. 1294 m; 22 Mar. 2008. • A.R. Marshall 1695 (K); Lushoto District, Ambangulu - PSP19, Ambangulu Tea Estate Forest, West Usambara Mountains; 54'20.69"S, 38²4'24.21"E; alt. 1294 m; 24 Mar. 2008. • F.M. Mbago 3586 (DSM); Lushoto District, Balangai forest near Tea estate; $4^{\circ} 56^{\prime} 41.24 " S$, 38²6'42.10"E; alt. 1505 m; 28 Jul. 2012. • F.M. Mbago 3760 (DSM), Korogwe Kunga Forest Mavimo Kwemtonto; 320'37.15"S, 37¹9'46.06"E; alt. 898 m; 23 Nov. 2016. • C.K. Ruffo 1730 (K); Muheza District, Kwamkoro F.R; alt. 950 m; 28 Oct. 1986. • C.K. Ruffo 1747 (K); Muheza District, Kwamkoro F.R; alt. 1000 m; 31 Jan. 1987. • C.K. Ruffo 1835 (K); Muheza District, Kwamkoro F.R; alt. 1050 m; 18 Sep. 1986.

\section{Key to the East African species of Uvariodendron}

1 Longest leaf lamina equal to or longer than $35 \mathrm{~cm}$ long ............................2

- $\quad$ Longest leaf lamina shorter than $35 \mathrm{~cm}$ long.............................................4

2 Number of secondary veins pairs equal to or less than 20; fruit monocarps less than $10 \mathrm{~mm}$ wide and with a length:width ratio over 5, stipe 5-11 mm long...

U. gorgonis (pro parte)

- $\quad$ Number of secondary veins pairs more than 20; fruit monocarps more than $13 \mathrm{~mm}$ wide and with a length:width ratio below 4, stipe less than $6 \mathrm{~mm}$ long 
$3 \quad$ Young branches sparsely pubescent to glabrous; leaf lamina oblong to obovate, base rounded to subcordate.......................................... U. usambarense

- $\quad$ Young branches pilose covered with long soft hair quickly falling off; leaf lamina obovate, base acute ..................................................... U. magnificum

4 Greatest leaf lamina equal to or shorter than $16 \mathrm{~cm}$ long, margins slightly revolute. .5

- Greatest leaf lamina longer than $16 \mathrm{~cm}$ long, margins flat..........................6

5 Bark and crushed leaves emitting a strong bergamot scent; flower and fruits (sub)sessile, pedicel less than $6 \mathrm{~mm}$ long; carpels 12 to 16; monocarps cylindrical, green-grey, tomentose with regular tufts of higher hair density

U. mbagoi

- $\quad$ Bark and crushed leaves not emitting a bergamot scent; flower and fruits pedicel 8-30 mm long (but flower buds sessile); carpels 50 to 75; monocarps ovoid, golden-brown, densely pubescent.....

U. dzomboense Leaf lamina up to $40 \mathrm{~cm}$ long, base rounded to acute; carpels 40 to 50; monocarp length:width ratio over 5 U. gorgonis (pro parte)

- $\quad$ Leaf lamina up to $32 \mathrm{~cm}$ long, base acute to decurrent; carpels up to 40; monocarp length:width ratio below 4 .7

7 Leaf lamina apex attenuate to acuminate; flower pedicel equal to or less than $15 \mathrm{~mm}$; sepals fused at base over more than $20 \%$ of their length 8

- $\quad$ Leaf lamina apex acute to attenuate; flower pedicel equal to or more than (5)$10 \mathrm{~mm}$; sepals connivent or fused at base over less than $10 \%$ of their length....9 Bark of trunk and branch peeling off, reddish; leaf lamina length:width ratio equal to or more than 3.4; petals 31-36 mm long, carpels 29 to 40

U. pycnophyllum

- $\quad$ Bark of trunk and branch not peeling off, greyish; leaf lamina length:width ratio equal to or less than 3.3; petals $10-12 \mathrm{~mm}$ long, carpels fewer than $10 \ldots$

U. schmidtii

$9 \quad$ Plant emitting a strong anise scent; longest leaves up to $32 \mathrm{~cm}$; flower pedicel 15-65 mm long; fruit monocarps 38-70 $\mathrm{mm}$ long, ripe fresh fruit dark blueblack

U. anisatum

- $\quad$ Plant not emitting anise scent; longest leaves up to $22 \mathrm{~cm}$; flower pedicel (5) 10-30 mm long; fruit monocarps $23-36 \mathrm{~mm}$ long, ripe fresh fruit dullorange.

U. kirkii

\section{Discussion}

The three new species described here (Uvariodendron mbagoi Dagallier \& Couvreur, Uvariodendron dzomboense Dagallier, W.R.Q. Luke \& Couvreur and Uvariodendron schmidtii W.R.Q. Luke, Dagallier \& Couvreur) occur in the coastal forests of Kenya and Tanzania. Due to their restricted ranges, they are all threatened following our IUCN preliminary conservation status assessments. Endemism is high in East Africa for plants 
and animals (Burgess et al. 1998, 2007), and single-location endemic species are known there (e.g. Scharff 1992, Couvreur et al. 2009, Gosline et al. 2019). The discovery of these three new narrowly endemic species supports this long-standing observation. This also shows that botanically this region is still not fully known despite the publication of the complete flora of East Africa (Beentje 2015). There are still new plant species that have been collected and await description (see e.g. "sp. nov." for several genera in Ngumbau et al. 2020).

The new combination and the three new species described here bring the number of East African Uvariodendron species to nine across East Africa, and to 17 across Africa. The described species show characters that have never been found in the family, such as the strong bergamot scent of Uvariodendron mbagoi or in the genus, such as the very densely pubescent carpels and monocarps of $U$. dzomboense.

\section{Acknowledgements}

We are grateful to COSTECH for delivering the necessary research permit (permit no. 2019-529-NA-2019-320) and all local authorities for permitting fieldwork in Tanzania. We are grateful to Yusuph Shekilango for the driving and technical support during this fieldwork mission, as well as to all the local guides. The visit to the $\mathrm{K}$ herbarium was made possible thanks to SYNTHESYS + grant (GB-TAF-45). We are very grateful to Aurélie Grall and all the Kew herbarium staff for the warm welcome. We are also grateful to B herbarium, EA herbarium and Dr Paul Musili, and MO herbarium for the loans of the specimens; to the P herbarium and Dr Thierry Deroin for allowing the visit to the collections. We thank very much the DSM herbarium and Botany Department of Dar es Salaam University, the MPU herbarium and especially Dr Caroline Loup, as well as the WAG herbarium and Dr Jan J. Wieringa for the welcome and hosting. This work was supported by the Agence Nationale de la Recherche (AFRODYN Grant Number: ANR-15-CE02-0002-01).

\section{References}

Beentje H (2015) Science comes from collaboration and communication: The Flora of Tropical East Africa as an example. Webbia 70(1): 171-179. https://doi.org/10.1080/00837792.2 015.1013244

Boutique R (1951) Annonacées nouvelles de la flore du Congo Belge et du RuandaUrundi. Bulletin du Jardin botanique de l'État a Bruxelles 21: 95-126. https://doi. org/10.2307/3666813

Burgess ND, Clarke GP, Rodgers WA (1998) Coastal forests of eastern Africa: Status, endemism patterns and their potential causes. Biological Journal of the Linnean Society. Linnean Society of London 64(3): 337-367. https://doi.org/10.1111/j.1095-8312.1998.tb00337.x 
Burgess ND, Butynski TM, Cordeiro NJ, Doggart NH, Fjeldså J, Howell KM, Kilahama FB, Loader SP, Lovett JC, Mbilinyi B, Menegon M, Moyer DC, Nashanda E, Perkin A, Rovero F, Stanley WT, Stuart SN (2007) The biological importance of the Eastern Arc Mountains of Tanzania and Kenya. Biological Conservation 134(2): 209-231. https://doi. org/10.1016/j.biocon.2006.08.015

Chatrou LW, Pirie MD, Erkens RHJ, Couvreur TLP, Neubig KM, Abbott JR, Mols JB, Maas JW, Saunders RMK, Chase MW (2012) A new subfamilial and tribal classification of the pantropical flowering plant family Annonaceae informed by molecular phylogenetics. Botanical Journal of the Linnean Society 169(1): 5-40. https://doi.org/10.1111/j.10958339.2012.01235.x

Cheek M (2003) A new species of Afrothismia (Burmanniaceae) from Kenya. Kew Bulletin 58(4): 951-955. https://doi.org/10.2307/4111208

Couvreur TLP (2009) Monograph of the syncarpous African genera Isolona and Monodora (Annonaceae). Systematic Botany Monographs 87: 1-150.

Couvreur TLP, Luke WRQ (2010) A new species of Uvariopsis (Annonaceae), endemic to the Eastern Arc Mountains of Tanzania. Blumea 55: 68-72. https://doi. org/10.3767/000651910X499196

Couvreur TLP, Niangadouma R (2016) New species of Uvariopsis (Annonaceae) and Laccosperma (Arecaceae/Palmae) from Monts de Cristal, Gabon. PhytoKeys 68: 1-8. https://doi. org/10.3897/phytokeys.68.9576

Couvreur TLP, Gereau RE, Wieringa JJ, Richardson JE (2006) Description of four new species of Monodora and Isolona (Annonaceae) from Tanzania and an overview of Tanzanian Annonaceae diversity. Adansonia 28: 243-266.

Couvreur TLP, Chatrou LW, Sosef MS, Richardson JE (2008) Molecular phylogenetics reveal multiple tertiary vicariance origins of the African rain forest trees. BMC Biology 6(1): e54. https://doi.org/10.1186/1741-7007-6-54

Couvreur TLP, van der Ham RWJM, Mbele YM, Mbago FM, Johnson DM (2009) Molecular and morphological characterization of a new monotypic genus of Annonaceae, Mwasumbia, from Tanzania. Systematic Botany 34(2): 266-276. https://doi. org/10.1600/036364409788606398

Couvreur TLP, Maas PJM, Meinke S, Johnson DM, Kessler PJA (2012) Keys to the genera of Annonaceae. Botanical Journal of the Linnean Society 169(1): 74-83. https://doi. org/10.1111/j.1095-8339.2012.01230.x

Critical Ecosystem Partnership Fund (2005) Eastern Arc Mountains and coastal forests of Tanzania and Kenya. Conservation International, International Centre of Insect Physiology and Ecology (Eds). [Available from:] https://www.cepf.net/sites/default/files/final.easternarc.ep_.pdf

Dagallier LMJ, Janssens SB, Dauby G, Blach-Overgaard A, Mackinder BA, Droissart V, Svenning J, Sosef MSM, Stévart T, Harris DJ, Sonké B, Wieringa JJ, Hardy OJ, Couvreur TLP (2020) Cradles and museums of generic plant diversity across tropical Africa. The New Phytologist 225(5): 2196-2213. https://doi.org/10.1111/nph.16293

Dauby G, Stévart T, Droissart V, Cosiaux A, Deblauwe V, Simo-Droissart M, Sosef MSM, Lowry PP II, Schatz GE, Gereau RE, Couvreur TLP (2017) ConR: An R package to assist 
large-scale multispecies preliminary conservation assessments using distribution data. Ecology and Evolution 7(24): 11292-11303. https://doi.org/10.1002/ece3.3704

Deroin T, Luke WRQ (2005) A new Toussaintia (Annonaceae) from Tanzania. Journal of East African Natural History 94(1): 165-174. https://doi.org/10.2982/00128317(2005)94[165:ANTAFT]2.0.CO;2

Fries RE (1930) Revision der arten einiger Anonaceen-gattungen. Acta Horti Bergiani 10: 51-65.

Friis I, Darbyshire I, Wilmot-Dear CM, Luke WRQ (2015) Pilea nguruensis (Urticaceae), a new species from the Eastern Arc Mountains, central Tanzania. Kew Bulletin 70(2): 1-24. https://doi.org/10.1007/s12225-015-9573-x

Gosline G, Marshall AR, Larridon I (2019) Revision and new species of the African genus Mischogyne (Annonaceae). Kew Bulletin 74(2): 1-28. https://doi.org/10.1007/s12225019-9804-7

Guo X, Tang CC, Thomas DC, Couvreur TLP, Saunders RMK (2017) A mega-phylogeny of the Annonaceae: Taxonomic placement of five enigmatic genera and support for a new tribe, Phoenicantheae. Scientific Reports 7(1): e7323. https://doi.org/10.1038/s41598017-07252-2

Hall JB, Rodgers WA (1986) Pole cutting pressure in Tanzanian forest. Forest Ecology and Management 14(2): 133-140. https://doi.org/10.1016/0378-1127(86)90098-8

Harris JG, Harris MW (2001) Plant identification terminology: an illustrated glossary. Spring Lake publishing, Spring Lake, Utah, Etats-Unis d'Amérique, 206 pp.

Hickey LJ, Ellis B, Daly DC, Johnson KR, Mitchell JD, Wilf P, Wing SL (1999) Manual of leaf architecture: morphological description and categorization of dicotyledonous and net-veined monocotyledonous angiosperms. Leaf Architecture Working Group, Washington, 65 pp.

Huber BA, Warui CM (2012) East African pholcid spiders: An overview, with descriptions of eight new species (Araneae, Pholcidae). European Journal of Taxonomy 29: 1-44. https:// doi.org/10.5852/ejt.2012.29

IUCN (2012) IUCN Red List Categories and Criteria: Version 3.1. Second Edition. IUCN, Gland, Switzerland and Cambridge, $32 \mathrm{pp}$.

Johnson DM, Mwasumbi LB, Mbago FM (1999) New species of Xylopia and Uvaria (Annonaceae) from Tanzania. Novon 9(1): 55-60. https://doi.org/10.2307/3392119

Johnson DM, Luke WRQ, Goyder DJ, Murray NA (2017) New species of Xylopia (Annonaceae) from East Africa. Kew Bulletin 72(1): 1-11. https://doi.org/10.1007/s12225-017-9681-x

Küper W, Sommer JH, Lovett JC, Mutke J, Linder HP, Beentje HJ, Van Rompaey RSAR, Chatelain C, Sosef M, Barthlott W (2004) Africa's hotspots of biodiversity redefined. Annals of the Missouri Botanical Garden 91: 525-535.

Le Thomas A (1965) Notes sur quelques Annonacées ouest-africaines. Adansonia ser. 2.

Le Thomas A (1967) A propos de l'Uvariodendron mirabile R. E. Fries. Adansonia VII: 249-253.

Le Thomas A (1969) Flore du Gabon 16 - Annonacées. Muséum National d'Histoire Naturelle, Paris, $371 \mathrm{pp}$.

Linder HP (2001) Plant diversity and endemism in sub-Saharan tropical Africa. Journal of Biogeography 28(2): 169-182. https://doi.org/10.1046/j.1365-2699.2001.00527.x

Marshall AR, Couvreur TLP, Summers AL, Deere NJ, Luke WRQ, Ndangalasi HJ, Sparrow S, Johnson DM (2016) A new species in the tree genus Polyceratocarpus (Annonaceae) from 
the Udzungwa Mountains of Tanzania. PhytoKeys 63: 63-76. https://doi.org/10.3897/ phytokeys.63.6262

Mwihomeke ST, Msangi TH, Mabula CK, Ylhäisi J, Mndeme KCH (1998) Traditionally protected forests and nature conservation in the North Pare Mountains and Handeni District, Tanzania. Journal of East African Natural History 87(1): 279-290. https://doi. org/10.2982/0012-8317(1998)87[279:TPFANC]2.0.CO;2

Myers N, Mittermeier RA, Mittermeier CG, Da Fonseca GA, Kent J (2000) Biodiversity hotspots for conservation priorities. Nature 403(6772): 853-858. https://doi. org/10.1038/35002501

Ngumbau VM, Luke WRQ, Nyange M, Wanga VO, Watuma BM, Mbuni YM, Munyao JN, Oulo MA, Mkala EM, Kipkoech S, Itambo M, Hu G-W, Wang Q-F (2020) An annotated checklist of the coastal forests of Kenya, East Africa. PhytoKeys 147: 1-191. https://doi. org/10.3897/phytokeys.147.49602

Paiva JAR (1966) Revisão das Annonaceae de Angola. Memórias da Sociedade Broteriana 19: 5-124. Patrick C (2008) An impact of invasive species Cedrela odorata L. on native plant species composition and diversity in Kimboza forest reserve; Morogoro, Tanzania. Thesis. University of Dar es Salaam. http://41.86.178.5:8080/xmlui/handle/123456789/13163

Payne WW (1978) A glossary of plant hair terminology. Brittonia 30(2): 239-255. https://doi. org/10.2307/2806659

Pellegrin F (1949) Les Annonacées du Gabon (suite). Bulletin de la Société Botanique de France 96(sup1): 52-73. https://doi.org/10.1080/00378941.1949.10839814

Poulsen AD, Lock JM (1997) New species and new records of Zingiberaceae and Costaceae from Tropical East Africa. Kew Bulletin 52(3): 601-616. https://doi.org/10.2307/4110289

QGIS Development Team (2016) QGIS Geographic Information System. Open Source Geospatial Foundation Project. https://qgis.org

R Core Team (2016) R: A Language and Environment for Statistical Computing. R Foundation for Statistical Computing, Vienna, Austria. https://www.R-project.org/

Scharff N (1992) The linyphiid fauna of eastern Africa (Araneae: Linyphiidae)-distribution patterns, diversity and endemism. Biological Journal of the Linnean Society. Linnean Society of London 45(2): 117-154. https://doi.org/10.1111/j.1095-8312.1992.tb00635.x

Schmidt R (1992) Degradation of a forest in the Shimba Hills National Reserve, Kenya, as initiated by man and maintained by wildlife. In: Goldammer JG (Ed.) Tropical Forests in Transition: Ecology of Natural and Anthropogenic Disturbance Processes. Advances in Life Sciences. Birkhäuser, Basel, 85-104. https://doi.org/10.1007/978-3-0348-7256-0_6

Sosef MSM, Dauby G, Blach-Overgaard A, van der Burgt X, Catarino L, Damen T, Deblauwe V, Dessein S, Dransfield J, Droissart V, Duarte MC, Engledow H, Fadeur G, Figueira R, Gereau RE, Hardy OJ, Harris DJ, de Heij J, Janssens S, Klomberg Y, Ley AC, Mackinder BA, Meerts P, van de Poel JL, Sonké B, Stévart T, Stoffelen P, Svenning J-C, Sepulchre P, Zaiss R, Wieringa JJ, Couvreur TLP (2017) Exploring the floristic diversity of tropical Africa. BMC Biology 15(1): 1-23. https://doi.org/10.1186/s12915-017-0356-8

Systematics Association Committee for Descriptive Biological Terminology (1962) II. Terminology of Simple Symmetrical Plane Shapes (Chart 1). Taxon 11(5): 145-156. https://doi. org/10.2307/1216718 
Verdcourt B (1955) Notes from the East African Herbarium: III. Kew Bulletin 10(4): 595609. https://doi.org/10.2307/4113772

Verdcourt B (1969) The genus Uvariodendron (Engl. \& Diels) R. E. Fries (Annonaceae) in East Africa. Kew Bulletin 23(3): e511. https://doi.org/10.2307/4117202

Verdcourt B (1971) Flora of Tropical East Africa: Annonaceae. Kew Publishing, 131 pp. https://doi.org/10.2307/4103132

Verdcourt B (1986) New taxa of East African Annonaceae. Kew Bulletin 41(2): e287. https:// doi.org/10.2307/4102932

Verdcourt B, Mwasumbi LB (1988) A new species of Uvaria (Annonaceae) from Tanzania. Kew Bulletin 43(1): 99-101. https://doi.org/10.2307/4118038

Vignes Lebbe R, Chesselet P, Diep Thi M-H (2016) Xper3: new tools for collaborating, training and transmitting knowledge on botanical phenotypes. In: Rakotoarisoa N, Loizeau P, Palese R, UNESCO (Eds) Botanists of the twenty first century: roles, challenges and opportunities. UNESCO, Paris.

Vollesen K (1980) Notes on Annonaceae from Tanzania. Botaniska Notiser 133: 53-62. 